\title{
Bacterial Contamination of a Phenolic Disinfectant
}

\author{
N. A. SIMMONS,* M.B., M.C.PATH.; D. A. GARDNER, † M.R.C.S.
}

\begin{abstract}
Ummary : Twenty ward stock bottles of aqueous $1 \%$ Printol were examined and 17 were found to be contaminated with Alcaligenes faecalis. Organisms were present in dead space behind the plastic liners of the boitle caps, where they could have survived washing. A. faecalis was also isolated from 31 out of $341 \%$ Printol solutions in use in the hospital. Pseudomonas aeruginosa was grown from two samples of $1 \%$ Printol in one ward, but not from stock bottles.

The minimal bactericidal concentration (M.B.C.) in aqueous solution of Hycolin, Sudol, and Stericol for A. faecalis and Ps. aeruginosa was 1 in 320. The M.B.C. of Printol for both organisms was 1 in 80 . The activity of all four disinfectants was reduced in the presence of large amounts of orgaric matter. Sudol was the least affected. Polyethylene, of which stock bottles were made, did not reduce the activity of the disinfectants. It is suggested that, ideally, stock bottles of disinfectant diluted ready for use should be autoclaved before they are refilled.
\end{abstract}

\section{Introduction}

Bacterial contamination of ward stock bottles of hospital disinfactants is not unknown. Mitchell and Hayward (1966) reported contamination of stock bottles of aqueous solutions of Hibitane (chlorhexidine) 1 in 5,000 with a previously unidentified Pseudomonas species, and Linton and George (1966) subsequently reported the presence of the same organism in many stock bottles of the same solution in hospitals in the same area. Burdon and Whitby (1967) reported the contamination of unopened and unused bottles of aqueous solutions of chlorhexidine 1 in 200 and Savlon 1 in 30 (chlorbexidine 1 in 200 and cetrimide 1 in 20) with Pseudomonas species. Kelsey and Maurer (1966) reported contamination of white fluid disinfectant with a Klebsiella species, but widespread contamination of stock bottles of solutions of other phenolic distinfectants commonly used in hospitals is less well known, and in this paper we report a situation in which bottles of $1 \%$ Printol were found to be heavily contaminated with Alcaligenes faecalis. At the same time Printol solutions from other sources in the hospital were found to be contaminated Fith Pseudomonas aeruginosa. We subsequently compared the M.B.C. of four commonly used phenolic disinfectants for these two organisms.

In this hospital aqueous disinfectant solutions ready for use are dispensed by the pharmacy in high-density polyethylene bottles, and, as Leigh and Whittaker (1967) had described, the apparent inactivation of disinfectants by plastic floor mops made of polyurethane foam we investigated the effect of polyethylene on the bacterial activity of the disinfectants. At the same time we investigated the effect on their activity of large amounts of organic matter.

\section{Methods}

\section{Examination of Printol Solutions taken from Wards}

$1 \%$ solutions of Printol were prepared ready for use by the hospital pharmacy and stored in wards in high-density polyethylene bottles, each of which held about 1 litre. Bottles of disinfectant taken from the wards and pharmacy were examined. $0.1 \mathrm{ml}$. of disinfectant or swabs dipped in the bottles were transferred to $10 \mathrm{ml}$. of Robertson's cooked meat broth, which was incubated at $37^{\circ}$ for 18 hours and then subcultured to blood agar, which was incubated under aerobic and anaerobic conditions for 18 hours. $1 \%$ Printol from other sources in the hospital was examined in the same way. Viable bacterial counts were carried out on $1 \%$ Printol from two bottles by the method of Miles and Misra (1938).

\section{M.B.C.s of Hycolin, Printol, Sudol, and Stericol -}

After the investigation of Printol described above, the manufacturers changed its formulation. The investigations described below were carried out with the new preparation.

The two organisms for which the M.B.C.s were determined were a Ps. aeruginosa and an $A$. faecalis isolated from disinfectant solutions in use in the hospital. With each disinfectant the procedure was the same. A 1-in-40 dilution was prepared by adding 0.5 to $19.5 \mathrm{ml}$. of sterile distilled water, and from this doubling dilutions of disinfectant from 1 in 40 to 1 in 640 were made. An attempt was made to prepare a solution of Printol stronger than 1 in 40 , but this proved difficult owing to the formation of a gel at higher concentrations. At each dilution $1 \mathrm{ml}$. of disinfectant was inoculated with $0.02 \mathrm{ml}$. of an 18-hour broth culture of the test organisms and incubated for 18 hours. This inoculum was shown to contain about $10^{8}$ organisms. Subcultures were then made from each tube on to blood agar, which was incubated for 18 hours, and the M.B.C. was read from the tube whose subculture was sterile. Subcultures were taken again from tubes after seven days' incubation and the results compared with those after 18 hours.

To determine the influence of organic matter on the bactericidal activity the same tests were carried out with disinfectant solutions made up in infusion broth containing $20 \%$ horse serum, the results being compared with those obtained with aqueous solutions.

To determine the influence of polyethylene on the activity, M.B.C.s were determined with both aqueous and serum broth solutions and a piece of clean sterile polyethylene, about 10 by 5 by $2 \mathrm{~mm}$., which had been cut from the wall of a plastic bottle, was added to each tube. The results were then compared with those obtained from tubes without plastic.

\section{Results}

\section{Examination of Printol taken from Wards}

Twenty bottles of $1 \%$ Printol were examined, of which 17 yielded a growth of organisms subsequently identified as $A$. faecalis. Viable bacterial counts carried out on two bottles showed the number of organisms present to be $2,500 / \mathrm{ml}$. in one bottle and $5,500 / \mathrm{ml}$. in the other. Examination of the

- Consultant Pathologist, Chase Farm Hospital, Enfield, Middlesex. † Registrar, Chase Farm Hospital, Enfield, Middlesex. Present address : Department of Clinical Pathology, Guy's Hospital, London S.E.1. 
bottles showed that within their screw caps there was a plastic liner behind which there was an area of dead space. Swabs taken from this space in contaminated bottles yielded the same organism. Printol from 34 other sources was examined and A. faecalis was isolated from 31. Ps. aeruginosa was isolated from $1 \%$ Printol used in a suction apparatus and $1 \%$ Printol in which a nail-brush was stored on one ward. The two isolates of Ps. aeruginosa were indistinguishable, as were the isolates of A. faecalis, and the characteristics of these organisms are given in Table I. Neither of these organisms could be isolated from the water or apparatus used in the hospital pharmacy to prepare the Printol solutions.

TABLE I.-Characteristics of Organisms

\begin{tabular}{|c|c|c|c|c|c|}
\hline & & & & A. faecalis & Ps. aeruginosa \\
\hline \multicolumn{6}{|r|}{ Neg. Bacillus } \\
\hline Motility .. & .. & .. & . & + & + \\
\hline Oxidase .. & . & & .. & + & + \\
\hline $\begin{array}{l}\text { Catalase } . \text { Glucose oxidation-f } \\
\text { Glu }\end{array}$ & & $\ddot{0}$ test & .. & + & \\
\hline \multicolumn{4}{|c|}{ Glucose oxidation-fermentation test .. } & $\overline{+}$ & Oxidation \\
\hline \multicolumn{4}{|c|}{$\begin{array}{lll}\text { Growth on nutrient agar } & . . & \ldots \\
\text { Growth on MacConkey's agar } & \ldots\end{array}$} & $\stackrel{+}{+}$ & + \\
\hline Citrate utilization & .. & & .. & - & + \\
\hline Gelatin hydrolysis & . & .. & . & - & + \\
\hline Urease $\quad \ldots$ & . & .. & .. & - & - \\
\hline Nitrate reduction & .. & .. & .. & + & + \\
\hline Gluconate oxidation & .. & & . & - & \\
\hline Pigment & . & . & . & Brown diffusible & Green diffusible \\
\hline
\end{tabular}

\section{Minimal Bactericidal Concentrations}

There was no clearly demonstrable change in the M.B.C. of any disinfectant for either organism after prolonged incubation (Table II). In aqueous solution the 'M.B.C. of Sudol and Stericol for both organisms was 1 in 320 , and the same concentration of Hycolin proved to be effective against Ps. aeruginosa. Printol was effective against Ps. aeruginosa in a concentration of 1 in 80 . Although Hycolin apparently became less effective and Printol more effective against $A$. faecalis after seven days' incubation, the difference in each case was of only one tube, and the M.B.C. of Hycolin for this organism was considered to be 1 in 320 and of Printol 1 in 80 .

\begin{tabular}{|c|c|c|c|}
\hline Disinfectant & Organism & $\begin{array}{l}\text { M.B.C. } \\
\text { A.queous Solutions }\end{array}$ & $\begin{array}{l}\text { M.B.C. of Serum } \\
\text { Broth Solutions }\end{array}$ \\
\hline Hycolin & $\begin{array}{l}\text { Ps. acrugincsa } \\
\text { A. faecaiis }\end{array}$ & $\begin{array}{l}1 \text { in } 320 \\
1 \text { in } 320^{*}\end{array}$ & $\begin{array}{l}1 \text { in } 80 \\
1 \text { in } 80\end{array}$ \\
\hline Printol & $\begin{array}{l}\text { Ps. aeruginosa } \\
\text { A. faecalis }\end{array}$ & $\begin{array}{l}1 \text { in } 80 \\
1 \text { in } 80 t\end{array}$ & $\begin{array}{l}1 \text { in } 80 \\
1 \text { in }<40\end{array}$ \\
\hline Sudol & $\begin{array}{l}\text { Ps. aeruginosa } \\
\text { A. faecalis }\end{array}$ & $\begin{array}{l}1 \text { in } 320 \\
1 \text { in } 320\end{array}$ & $\begin{array}{l}1 \text { in } 320 \\
1 \text { in } 160\end{array}$ \\
\hline Stericol & $\begin{array}{l}\text { Ps. aeruginosa } \\
\text { A. faecalis }\end{array}$ & $\begin{array}{l}1 \text { in } 320 \\
1 \text { in } 320\end{array}$ & $\begin{array}{l}1 \text { in } 80 \\
1 \text { in } 40\end{array}$ \\
\hline
\end{tabular}

- This was the result after 7 days' incubation. The M.B.C. after 18 hours appeared to be 1 in 640 .
This was the result after 15 hours' incubation. The M.B.C. after 7 day
appeared to be 1 in 160 .

The bactericidal activity of the disinfectants was reduced by making up the solutions in serum broth. This effect was considerable with Hycolin, whose M.B.C. for both organisms was reduced to 1 in 80 , with. Stericol in which it was reduced to 1 in 80 for Ps. aeruginosa and 1 in 40 for A. faecalis, and with Printol, of which a broth solution sufficiently concentrated to kill $A$. faecalis could not be prepared. Sudol was the least affected, and its M.B.C. for Ps. aeruginosa was unchanged.

The presence of polyethylene in broth or aqueous solutions did not alter the M.B.C.s.

\section{Discussion}

When this investigation was initiated Printol was the disinfectant most commonly used in our hospital, and, though we were unable to obtain clear bacteriological proof that the organisms found in the ward stock bottles had caused clinical infection, the widespread contamination obviously constituted a serious hazard. It was the practice for empty bottles to be returned to the pharmacy, where they were replaced by others which had been thoroughly washed in hot water and refilled. It is apparent that washing failed to remove contaminating bacteria, which remained in the bottles that were then recirculated throughout the hospital. It is known that bark corks may protect bacteria from the sction of cetrimide (Lowbury, 1951 ; Anderson and Kegnes, 1958). Linton and George (1966) showed that they may also inactivate chlorhexidine, and they recommended that screw caps with rubber or plastic liners should be used instead. We have shown that these too may be unsafe, for bacteria may persist to the dead space behind liners when bottles are washed. Leigh and Whittaker (1967) demonstrated the apparent inactivation of Roccal and Hycolin by polyurethane foam, but we were unable to demonstrate any inactivation by polyethylene of the four disinfectants we examined.

Kelsey and Maurer (1966) recommended that stock bottles of disinfectant diluted ready for use should be autoclaved before they are refilled. We agree with them, but in this hospital it has not proved to be wholly practicable. Instead, solutions of Sudol, which is the disinfectant in current use, are now dispensed in two types of bottle. When they are required for " household" purposes, such as the storage of lavatory brushes, they are issued in plastic bottles which have simply been washed and with the liners removed from their caps. When they are required for "surgical "purposes they are issued in glass bottles which have been autoclaved. Nail-brushes are no longer used in the wards, and the only "surgical" purpose for which the solutions are employed is the storage of Cheatle forceps. We recognize that autoclaving is the only satisfactory method of wet-heat.sterilization, but boiling water is the only method available in many of our wards, and therefore Cheatle forceps remain a necessary evil.

We are fully aware that the tests we employed to determine the bactericidal activity of the four disinfectants were extremely stringent, for the inoculum size and the amount of organic matter added were considerable. We would not expect to encounter these conditions in practice, but disinfectants which show adequate bactericidal activity under these circumstances are likely to do the same when the conditions are less extreme.

This report is not meant to be a recommendation for any particular disinfectant. The bactericidal properties of thos: we examined may be different when they are tested with other organisms, and one which is highly bactericidal may prove to be unsatisfactory in other respects.

We wish to thank Mr. D. J. McGillicuddy, a research technician supported by grants from Lederle Laboratories and the North-eas? Metropolitan Regional Hospital Board, for able technical assistance.

\section{REFERENCES} Anderson, K., and Keynex, R. (1958). British Medical Yournal, 2, 274.
Burdon, D. W., and Whitby, J. L. (1967). British Medical Yourral, 2, 153. D. W., and Whitby, I. L. (1967). British Medical Yourmal, 2, Relsey, J. C., and Maurer I. M. (1966). Monthly Bulletin of the Ministry of Health and the Public Health Laboratory Service, 25, 180.

Lelgh, D. A., and Whittaker, C. (1967). British Medical Yournal, 3, 435 Linton, K. B., and George, B. (1966). Lancet, 1, 1353.

Lowbury, E. J. L. (1951). British Fournal of Industrial Medicine, 8, 22.

Miles, A. A., and Misra, S. S. (1938). Yournal of Hygiene, 38, 732.

Mitchell, R. G., and Hayward, A. C. (1966). Lancet, 1, 793. 